\title{
Von Recklinghausen's disease and melanoma of the uvea
}

\author{
JEAN NORDMANN AND ALFRED BRINI \\ Strasbourg, France
}

In 1882 Professor von Recklinghausen, Director of the Institute of Pathology at our University published his original work. "Über die multiplen Fibrome der Haut und ihre Beziehung zu den multiplen Neuromen". Since that time neurofibromatosis, which bears his name, has been the subject of many reports; in addition to the cutaneous lesions characterized by multiple neuromata and café au lait spots, numerous other manifestations have been described.

Our understanding of these clinical features has been clarified by the work of Masson (1926), Director of the same Institute, and of Oberling (1922), his associate professor from 1919 to 1926. The former showed the close relationship between Schwann cells and dermal melanoblasts and the latter recognized the nature of the meningoblast as homologous to the Schwann cell.

In most cases the neurofibromatosis of von Recklinghausen becomes a disease of the schwannian system, but the neoplasia of the nervous system proper still requires to be explained. Fig. I shows that, if the Schwann cells and pigment cells arise from the neural crest, this derives from the primitive neuroectoderm, which also gives rise to the other neural elements. When development extends beyond the cells of Schwann-though this is relatively rare-any differentiation of the neuroectoderm can result.

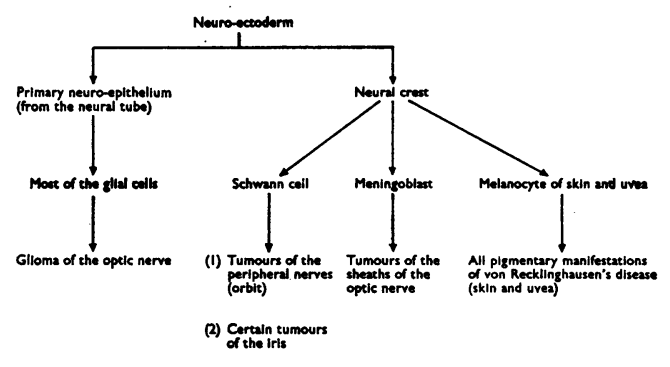

FIG. I Possible evolutions of the neuroectodermal cell.

Are these conclusions regarding the origin and nature of the cells valid also for the eye? They are true for tumours of the sheaths and of the optic nerve itself (Oberling and Nordmann, 1927; Paufique, 1928). The origin and nature of the melanocytes of the uvea, and of neoplasia derived from them, have been extensively discussed (Strakhov, I94I ; Nordmann and Brini, I95 I Brihaye-van Geertruyden, I963a, b; Duke-Elder and 
Perkins, I966; Feyrter and Böck, 1970). Our knowledge of these tumours is now precise as a result of numerous anatomo-pathological observations, of which we will quote only those of Dvorak-Theobald (1937), Nordmann (I938, I947a, b, c), Nordmann and Hoerner (1947), and Nordmann and Burger (1958); which emphasize their neural and schwannian characteristics. The embryological research of Nordmann and Stoll (1947) and the experiments of Brini (1949, I95 I) and of Brihaye-van Geertruyden (1963) show that melanocytes of the uvea derive, like those of the skin, from the neural crest, even in mammals. The majority of benign and malignant neoplasms of the uveal tract may be considered as composed of nerve cells similar to schwannian elements.

A relationship may therefore be expected to exist between von Recklinghausen's disease and melanoma of the uveal tract, and it seemed advisable to seek for support for this hypothesis. For further detailed analysis we separated the classical form of neurofibromatosis from its formes frustes and from atypical manifestations.

\section{Uveal melanomata in classical von Recklinghausen's disease}

In the classical form of the disease the skin lesions are numerous and dominate the clinical picture. In the iris, uniform dispersion of pigment (Kulkow, I933), heterochromia, ectropion, and coloboma have been described (Waardenburg, I963; Duke-Elder and Perkins, 1966), and, in particular, pigmented spots as well as small nodules. We eliminated those cases in which pigmentation was not mentioned or was definitely absent (Waardenburg, I932a,b, I942; Sakurai, I935; Tichomirow and Kopziowskaja, I937; Streiff, 1957), and retained for the purpose of our study only 'naevi' and melanomata o\$ the iris.

In von Recklinghausen's disease such appearances have frequently been described. Pietruschka (1952, I959, I96I) examined 33 patients with classical von Recklinghausen's disease and in $3 \mathrm{I}$ was able to demonstrate 'phakomas' in the iris, all bilateral. Waardenburg ( 1963 ) found them in 29 of 31 cases of neurofibromatosis and we ourselves found them in ten of eleven cases.

The irides in these eyes are studded with pigmented spots, but these have no characteristic features except when a true benign melanoma is seen to develop, as in the patient described by Verbeck ( 1969 ), or when one discovers in both eyes, on slit-lamp examination, a varying number of tiny rounded, superficial, and slightly raised nodules, ranging in colour from light yellow to brown (Fig. 2, opposite).

The histology of sections of iris nodules of this type occurring in neurofibromatosis has been described by Goldstein and Wexler (1930), van der Hoeve (1932), Reese (I951), Meisner and Unger (1954), and Wolter and Butler (1963).

In the other parts of the uveal tract, the ciliary body, and the choroid, a benign pigmented lesion is rarely found in classical von Recklinghausen's disease. Goldstein and Wexler (1930) reported melanosis of the choroid and Pietruschka (1959) saw a choroidal naevus once only in his series of 33 cases. In the eleven cases reviewed there was also one definite naevus at the posterior pole (Fig. 3, opposite); we followed this for 8 years without observing the smallest change. The other fundi were normal, and there was therefore a great difference between the anterior and posterior segments. In the first, nodules and benign melanomata are very common, and their association with neurofibromatosis is beyond dispute; in the latter, such lesions are exceptional and almost certainly not related to the disease.

* Goldstein and Wexler, 1930; Gabriélidès, 1931; van der Hoeve, 1932; Kurz, 1932, 1933; Merkulow 1935 ; Soriano and Piccoli, 1935; Lisch, 1937; Tamura and Higuti, 1940a,b; Machlin, I940; Unger, 1947; Walsh, I947; Reet, 1951; Georgiades, 1951; and Fritz, I959; Wolter and Butler, I963; Wolter, I965; Sokolova and Cherepanov, I965; Verbeck, í69; Fischer-von Bünau, I969. 


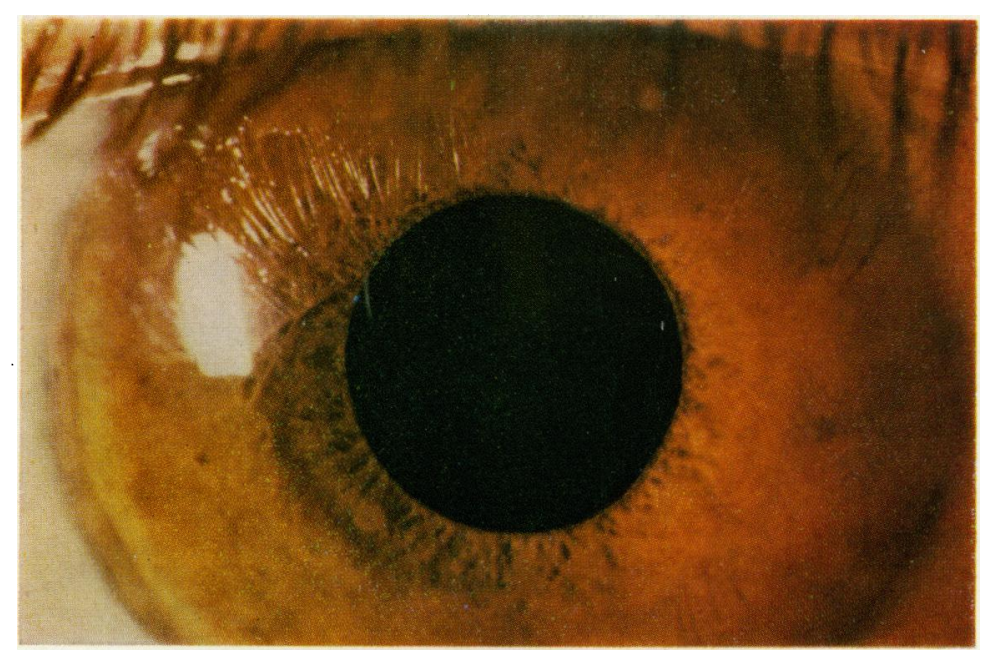

FIG. 2 Pigmented nodules of the iris in von Recklinghausen's disease
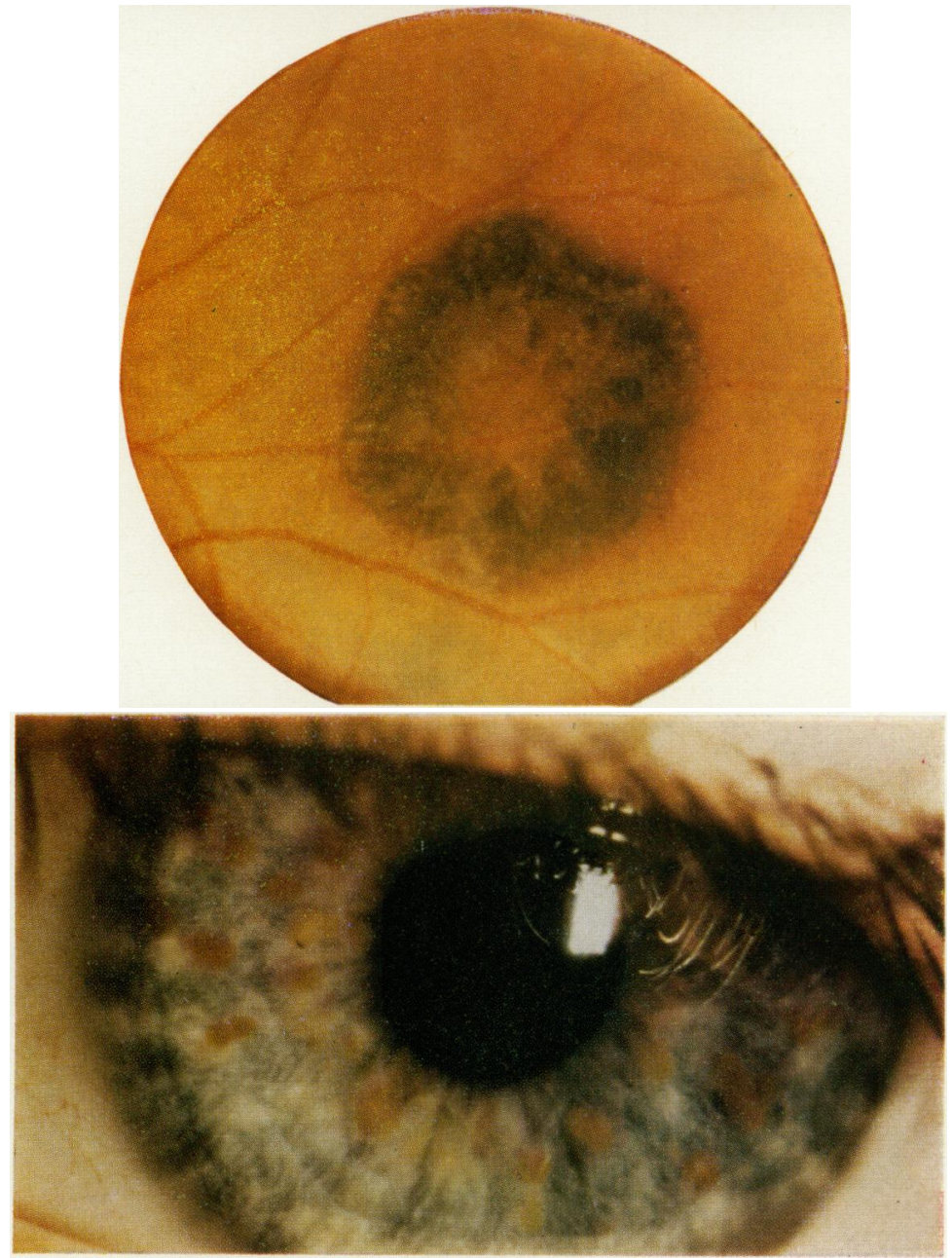

FIG. 3 "Naevus" of the choroid (in same patient as Fig. 2)

FIG. 7 Multiple nodules of the left iris (in same patient as Figs 4 to 6 ) 
In malignant melanoma the situation is very different. We did not see one which definitely arose in the iris, but the association between classical neurofibromatosis and malignant melanoma of the ciliary body and choroid seems to be definite. The observations of Gartner (1940), Strakhov and Shepkalova (1941), Szekler (1953), and Nordmann, Brini, and Ruolt ( 1963 ) support this.

\section{Uveal melanomata in formes frustes or atypical von Recklinghausen's disease}

When the cutaneous manifestations are few and discrete, perhaps confined to occasional café au lait spots and a few neurinomata or none, this can be regarded as a forme fruste.

According to Pietruschka (1959), the characteristic benign anomalies of the iris are then less frequent. This group includes the case described by Grimsdale (1899) and those of Reese (1952).

This association of cutaneous naevi and iris melanomata is also found in the choroid, but here there is a definite preponderance of malignant tumours. Mawas (I93 I) was the first to show the importance and relative frequency of the syndrome of cutaneous naevi and choroidal neoplasia, and the examples described by Nordmann (1947, 1961, r963) show that this observation was well founded.

The 'schwannoma' reported by François (1947) adds further support, but the neurofibroma of Moorhouse (1939) shows different skin lesions.

Benign and malignant melanomata of the uvea can thus coexist with marked or trivial cutaneous manifestations. This also applies to tumours of the optic nerve, which were described in association with von Recklinghausen's disease by Emanuel ( 1901 ); it did not become widely known until it was observed by Davis (1940) and Bürki (I944) but is now generally accepted (Offret, I95I; Reese, I952; Manschot, 1954). According to Davis (1940) optic nerve tumours are more often associated with formes frustes, and the few café au lait spots or small skin neoplasia easily escape notice.

Merkulow (1935) described a case of neurofibromatosis in which a tumour of the optic nerve was suspected because of enlargement of the optic foramen; there were also scattered pigmented nodules in both irides. It is probable that this association between the skin, the optic nerve, and the iris would be recognized more frequently if slit-lamp examination of the anterior segments and $x$-ray examination of the optic canal were carried out more often.

The combination of a tumour of the optic nerve with melanomata of the iris allows the diagnosis of atypical von Recklinghausen's disease to be made even in the absence of any cutaneous anomaly.

\section{Case report}

A male infant aged 17 months was admitted to the Clinique Infantile, and then to the Clinique Neurologique (Case I0I6/64), with unilateral exophthalmos, which according to the relatives had appeared during the previous fortnight and had then remained stationary.

opHThalmological examination (Dr. Ketter, Luxembourg)

There was a partially reducible right exophthalmos with venous dilatation at the inner canthus. There was a collateral venous circulation in the forehead and temples. The globe was displaced downwards and outwards; elevation and adduction were limited.

The right fundus showed oedema of 4-5 dioptres localized to the optic disc. The veins were dilated and tortuous. The left fundus showed papilloedema of $I$ dioptre. 
A study of the photomotor reflexes and the child's behaviour during occlusion of the right and left eyes led to the conclusion that the right eye was blind.

\section{GENERAL EXAMINATION}

The child's development was normal for his age. He had walked alone at 14 months and had a good appetite, though there had been several attacks of vomiting.

The circumference of the head was increased; a cracked-pot note could be elicited. There was also marked separation of the sutures, and the right hemicranium bulged slightly more than the left. It was considered that these findings, together with the history of vomiting and the bilateral papilloedema, indicated a raised intracranial pressure.

On examination of the skin, several pigmented naevi were seen: over the right iliac crest, in the $\vec{\circ}$ axillae, on the left buttock and thigh, and on the right leg.

Neurological examination was negative apart from that of the eye already reported.

\section{FURTHER INVESTIGATIONS}

These were carried out to see whether there could be a lesion straddling the orbit and the anterior part of the skull:

$X$-ray of the optic foramina: Enlargement of the right optic foramen.

$X$-ray of the skull: No bony signs of raised intracranial pressure.

Fractional air encephalography: Fourth ventricle was displaced. Passage through aqueduct normal. Third ventricle normal in size and position. Foramen of Monro patent. Lateral ventricles were clearly outlined and filling normal in the region of the frontal and occipital horns. Cisternae of $\mathbb{\mathbb { E }}$ base of the skull and posterior fossa normal.

Electroencephalogram (attempted on several occasions, but with difficulty because of the child's age) Baseline activity showed unusual modulations which varied in different recordings. No definite evidence in favour of acute intracranial hypertension; but tracings could be interpreted as indicating a slowly progressive cerebral condition, possibly arising in the deeper centres. There was a slight asymmetry but no clear localizing signs.

\section{SURGERY}

Taken together these findings suggested the presence of an optic nerve tumour, and operation was performed on October 5, 1964 (Prof. Philippides) through a right frontal trephine. The optic nerve was considerably increased in volume, and the procedure was limited to resection of a segment of the nerve.

\section{HISTOLOGICAL REPORT ON OPTIG NERVE}

The optic nerve is the site of proliferation of astrocytes and spongioblasts of varying ages. The meninges are invaded by gliomatosis. This type of glioma can be classified as an astrocytoma or $\frac{O}{5}$ polar spongioblastoma. This is a tumour which is classically insensitive to radiotherapy.

COURSE

The postoperative period was normal, and a follow-up examination in the spring of 1966 showed $N$ protrusion and near-total downward displacement of the globe, only slightly reducible. The cornea showed a band-shaped degeneration. There were marked periorbital venous networks.

For cosmetic reasons enucleation was carried out in Luxembourg in August, 1966.

HISTOLOGICAL EXAMINATION OF ENUCLEATED GLOBE

A corneal opacity occupied the anterior half of the thickness of the stroma and was heavily vascularized. 
The eye was otherwise normal apart from the iris. This showed small accumulations of elongated cells with tapering extremities, grouped densely together whether in the thickness of the stroma or on the anterior surface of the iris, where they formed small raised areas (Figs 4 to 6). Depending on the site, these cells, which in shape resembled the melanocytes in the stroma, showed varying degrees of pigmentation: these lesions are benign melanomata of the iris, still referred to clinically as naevi, although their histological structure is only occasionally the same.

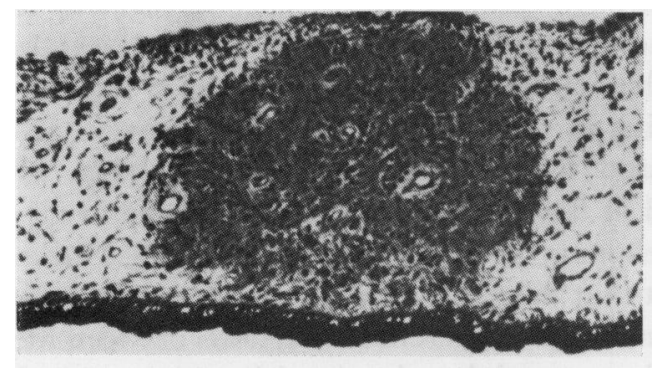

FIG. 4 Benign melanoma of the right iris occupying the whole thickness of the stroma. $\times 70$

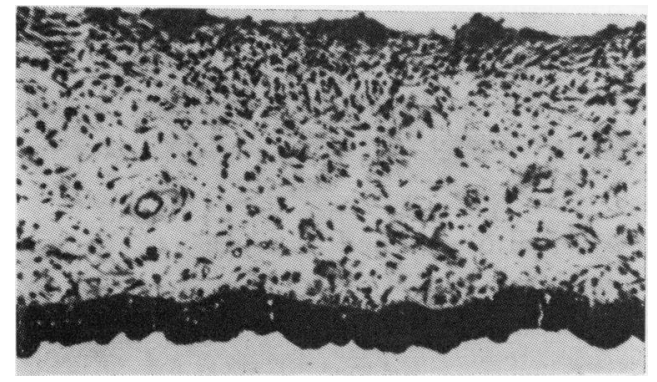

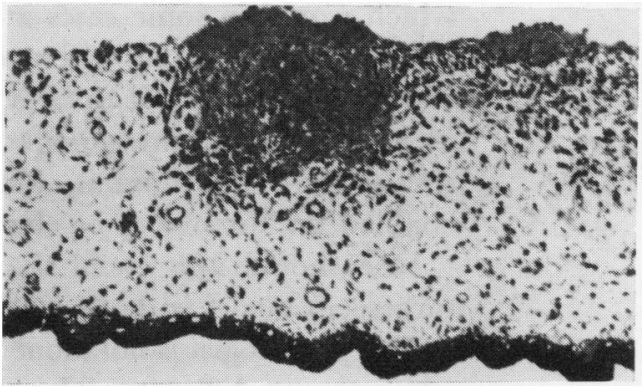

FIG. 5 Prominent benign melanomata on the anterior surface of the right iris. $\times 70$

FIG. 6 Multiple small superficial melanomata of the right iris. $\quad \times 70$

FOLLOW-UP

The most recent examination was carried out in January, 1970. The child's general condition was good, but the right prosthesis was displaced forwards by a tumoral mass in the apex of the orbital cavity.

The left eye showed raised yellow nodules in a blue-green iris (Fig. 7, see col. plate). The pupillary reactions were normal.

The optic disc was white and sharply outlined; the visual acuity could not be improved beyond 2/10.

As the iris nodules in von Recklinghausen's disease are always bilateral, it can be concluded that the melanomata discovered in sections of the right eye had been clinically identical with those later seen in the left.

\section{Discussion}

It should be remembered that what is true for the optic nerve is true also for others, in particular the acoustic nerve. The coexistence of a pigmented tumour of the uveal tract is suggestive of von Recklinghausen's disease even if the skin is completely normal. This was so in a patient reported by Stieda (I93I), who had several neurinomata; one ponto-cerebellar neurinoma and one iris neoplasm were diagnosed as melanosarcomata. 
Another example has been described by Bair and Love (1937), who operated on the patient for an acoustic neurofibroma and for a melanoepithelioma of the choroid.

The coexistence in the same patient of a glioma of the optic nerve and of iris melanomata음 can easily be understood on the basis of the neural origin of the uveal melanocyte.

The diagnosis of neurinoma or schwannoma has sometimes been made, but the histological sections do not appear to have been treated by Fontana's silver nitrate method, $\overline{0}$ which would in some cases at least have enabled the presence of pigment to be demon-क़्ल strated. An example is that of the brownish tumour described by François (1947); the@ clinician considered it to be a 'melanosarcoma', but the pathologist, finding no pigment, identified it as a schwannoma arising in the sheath of the ciliary nerve. In a somewhatsimilar case (Nordmann, Brini, and Ruolt, 1963; Nordmann, 1963), silver staining enabled the tumour to be classified in the group FB of tumours of the uveal tract.

One should also recall that melanotic neoplasia usually contain a large number of응. turgescent nuclei with nucleoli, but that these are definitely less common in neurinomata.j

The pathologist is not alone in finding the differential diagnosis between melanoma and schwannoma difficult. The clinician, examining the tiny iris nodule with the slit lamp,o may also wonder whether the pigment belongs to the tumour or only covers it. These cases are, however, exceptional, the colouring of the neoplasm itself is usually unequivocal.?

\section{Summary}

(x) In all the major clinical forms of von Recklinghausen's disease, examples of benign $\stackrel{\mathbb{\Phi}}{-}$ or malignant melanomata of the uveal tract may be found, and benign iris melanomaass extremely common.

(2) This fact accords with the theory-still questioned by some-of the neural origin uveal melanocytes. Our observations have shown that there may be an association between optic nerve tumours and von Recklinghausen's disease even if there is no majorö manifestation on the skin.

(3) In a patient with a uveal melanoma, it is wise to look for signs of von Recklinghausen's disease, particularly on the skin and (by radiography of the optic foramen) in the optic? nerve. Conversely, where they are cutaneous manifestations of von Recklinghausen's disease one should consider the possibility of a coexisting optic nerve or iris tumour.

\section{References}

AXt, E. (1958) Klin. Mbl. Augenheilk., 133, 798

BAIR, H. L., and love, J. G (1937) Proc. Mayo Clin., 12, 48 I

BRIHAYE VAN GEERTRUYDEN, M. (1963a) Arch. Biol., 74, I

(1963b) Docum. ophthal. (Den Haag), 17, 163

BRINI, A. (1949) Bull. Soc. Ophtal. Fr., p. 474

(195I) "L'origine du melanoblaste choroidien." Thèse méd., Strasbourg

BRONNER, A., ROTH, A., and FRITZ, B. (1959) Bull. Soc. Ophtal. Fr., p. 723

BÜRKI, E. (1944) Bibl. ophthal. (Basel), fasc. 30

CHODOS, J. B., and MAEDER, G. (1957) Ophthalmologica (Basel), 133, 237

DAvis, F. A. (1940) Arch. Ophthal. (Chicago), 23, 735; 957

DUKE-ELDER, s., and PERKINS, E. s. (1966) "System of Ophthalmology", vol. 9, p. 831. Kimpton,

London

DVORAK-THEOBAld, G. (1937) Arch. Ophthal. (Chicago), 18, 97 I

emanuel, c. (1901) von Graefes Arch. Ophthal., 53, 129 
FEYRTER, F., and BÖCK, J. (1970) Ibid., 179, I99

FISCHER-VON BÜNAU, H. (1969) Personal communication

FRANÇOIs, J. (1947) Ann. Oculist., 180, 542

GABRIÉLIDÈs, c. (I931) Ibid., 168, I87

gartner, s. (1940) Amer. F. Ophthal., 23, 73

GeORgiades, G. (195I) Bull. Soc. hellén. Ophtal., 19, 99

Goldstein, I., and WeXler, D. (1930) Arch. Ophthal. (Chicago), 3, 288

GRIMSDALE, H. B. (1899) Trans. ophthal. Soc. U.K., I9, 61

HAGER, G. (1958) Klin. Mbl. Augenheilk., 132, 350

HOEVE, J. VAN DER (1932) Trans. ophthal. Soc. U.K., 52, 38o

KUlkow, A. E. (1933) Mschr. Psychiatr., 86, 247

- (1934) Zbl. ges. Ophthal., 30, I 16

KURZ, J. (1932) Oftal. Sborn., 7, 58, 294

(1932) Bratislav. Lek. Listy 12, Suppl. 12, p. 162-3 and Abstr. p. I36

(1933) Zbl. ges. Ophthal., 28, 566, 786

LISGH, к. (1937) Z. Augenheilk., 93, 137

machlin, I. м. (г940) Vestn. Oftal., 16, 2 I 6

(1941) Zbl.ges. Ophthal., 46, 594

manschot, w. A. (1954) Brit. 7. Ophthal., 38, 285

masson, P. (1926) Ann. Anat. path. Anat. norm. med.-chir., 3, 41 7; 657

MAWAS, J. (r931) Bull. Soc. frang. Ophtal., 44, 37 I

MEISNER, G., and UNGER, H. H. (1954) Klin. Mbl. Augenheilk., 124, 466

MERKULOW, I. I. (1935) Augenveränderungen bei Neurofibromatose. Sbornik v. osn. sorok. nauc.

gejat. sasl. gejat nauki M. I. Auerbach, $280-287$

MOORHOUSE, J. H. (1939) Trans. ophthal. Soc. U.K., 59, $4^{1} 6$

nordmann, J. (1938) Bull. Soc. Ophtal. Paris, p. 300

-(1947) Bull. Soc. franc. Ophtal., 6o, 45

- (1947) Bull. Soc. Ophtal. Paris, p. 262

- (1947) Bull. Histol. appl., 24, 97

- (196r) Bull. Soc. Ophtal. Fr., p. $3^{22}$

- (1963) Confer. lyonn. Ophtal., 67, I

and BRINI, A. (I95 I) Docum. ophthal. (Den Haag), 5-6, 205

- -

and BURGer, A. (1958) Ophthalmologica (Basel), r35, 6 I 7

and hoerner, G. (1947) Bull. Soc. Ophtal. Patis, p. 259

and stoll, R. (1947) Ophthalmologica (Basel), r14, 99

Oberling, C. (1922) Bull. Ass. frang. Cancer, 11, 365

and nordmann, J. (1927) Ann. Oculist., 164, 56 I

OFFret, G. (195I) "Les tumeurs primitives de l'orbite”. Masson, Paris

PAUfiQUe, L. (1928) "Les tumeurs du nerf optique". Thèse méd., Lyon

pietruschKa, G. (1952) Klin. Mbl. Augenheilk., 121, 663

- (1959) Ber. Tagg. Augenärzte DDR, 3, 35 (1961) Med. Bild., 4, 8

RECKLINGHAUSEN, F. VON (1882) "Über die multiplen Fibrome der Haut und ihre Beziehung zu den multiplen Neuromen". Hirschwald, Berlin

REESE, A. B. (1951) "Tumors of the Eye", p. I 79. Hoeber, New York

- (1952) A.M.A. Arch. Ophthal., 48, 27 I

SAKURAI, T. (1935) Acta Soc. ophthal. jap., 39, I I, 87

SCHMÖGER, E. (1956) v. Graefes Arch. Ophthal., 157, 260

SOKolova, o. N., and CHerepanov, A. N. (1965) Oftal. Zh., 20, 26r

- (1966) Zbl. ges. Augenheilk., 96, I 44 
SORIANo, F. J., and PICCOLI, H. (1935) Arch. Oftal. B. Aires, 10, 620

stieda, A. (1931) Mschr. Psychiatr., 80, 7 I

$$
\text { (1932) Zbl. ges. Ophthal., 27, } 72
$$

STRAKHov, v. P., and Shepkalova, v. м. (1941) Vestn. Oftal., 18, 12

STREIFF, E. B. (1957) Ophthalmologica (Basel), 133, 24I

SZEKLER, R. (1953) Ibid., 126, 248

TAMURA, s., and higuti, K. (I940a) Chuo-Ganka-Iho, 32, No. 2, p. 47

- - (1940b) Zbl. ges. Ophthal., 45, $35^{6}$

TiGHOMirow, P. E., and KOPZIOWSKAJA, R. s. (1937) Vestn. Oftal., I1, 70

- - (1939) Zbl. ges. Ophthal., 42, 691

UNGER, K. (1947) Arch. Ophthal. (Chicago), 38, 654

verbeck, B. (1969) Klin. Mbl. Augenheilk., 155, 75I

WAARdenburg, P. J. (1932a) Ned. T. Geneesk., 76, 5508

(1932b) "Das menschliche Auge und seine Erbaulagen", p. 225. Nijhoff, The Hague (1942) Ned. T. Geneesk., 86, 1384

(1963) "Phacomatoses", in "Genetics and Ophthalmology", vol. 2, chap. 27, pp. 1344-

1350. Blackwell Scientific Publications, Oxford

WALSH, F. B. (1947) "Clinical Neuro-ophthalmology", p. 1075. Williams and Wilkins, Baltimore WOLter, J. R. (1965) Arch. Ophthal. (Chicago), 73, 696 and Butler, R. G. (1963) Amer. F. Ophthal., 56, 964 